\title{
DCAF7 wt Allele
}

National Cancer Institute

\section{Source}

National Cancer Institute. DCAF7 wt Allele. NCI Thesaurus. Code C104182.

Human DCAF7 wild-type allele is located in the vicinity of $17 q 23.3$ and is approximately 44 $\mathrm{kb}$ in length. This allele, which encodes DDB1- and CUL4-associated factor 7 protein, may be involved in regulation of transcription. 